\title{
Pengaruh Gaya Kepemimpinan Transformasional Motivasi Kerja Lingkungan Kerja Terhadap Kinerja Inovasi Karyawan (Studi Pada PT. PLN Persero ULP Kepulauan Kangean Kab.Sumenep)
}

\author{
Moh. Hafis Fahrulla
}

Universitas Sarjana Wiyata Tamansiswa Yogyakarta (UST), hafisfahrulla@gmail.com

\section{ARTICLES}

INFORMATON

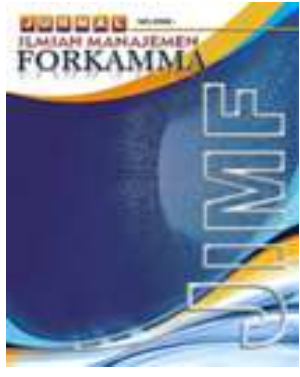

\section{JURNAL ILMIAH \\ MANAJEMEN FORKAMMA \\ Vol.4, No.2, Maret 2021 \\ Halaman : $148-161$ \\ (c) LPPM \& FORKAMMA \\ Prodi Magister Manajemen \\ UNIVERSITAS PAMULANG}

\section{ISSN (online) : :2599-171X ISSN (print) : :2598-9545}

\section{Keyword : \\ Gaya Kepemimpinan; \\ Transformasional; Motivasi Kerja; Lingkungan Kerja; dan Kinerja Inovasi Karyawan.}

\section{JEL. Classification : O15,}

Contact Author :

\section{PRODI}

MAGISTER MANAJEMEN \& FORKAMMA UNPAM

JL.Surya Kencana No. 1 Pamulang

Tanggerang Selatan - Banten

Telp. (021) 7412566, Fax (021) 7412491

Email

Jurnalforkamma.unpam@gmail.com
Tujuan dalam riset berikut di harapkan bisa memenuhi permaslahan yang berada didalam riset ini. Utuk menganalisa, mengetahui dan menjawab pengaruh Gaya Kepemimpinan Tranformasional, Motivasi Kerja, dan Lingkungan Kerja terhadap Kinerja Inovasi Karyawan pada PT. PLN ULP Kepulauan Kangean Kabupaten Sumenep, riset berikut menggunakan narasumber yang berjumlah 85 narasumbur yang dipilih dari pegawai yang bekeja di PT. PLN Persero ULP Kepulauan Kangean Kabupaten Sumenep dengan menggunakan teknik sampling jenuh.

Teknik riset regresi linier berganda ini secara keseluruhan indikator didalam variable yang bebas dan terikat, menunjukkan bahwa variabel bebas berpengaruh positif dan signifikan terhadap variabel terikat. Dalam hasil koefisien korelasi dan koefisien determinasi menunjukkan seluruh variabel bebas memiliki pengaruh yang kuat dan selaras terhadap varibel terikat sebesar $92,6 \%$, sedangkan sisanya sebesar $7,4 \%$ di pengaruhi oleh variabel lain yang tidak diteliti .

The purpose of the research is expected to be able to answer the problem formulation in the research thesis. To find out, analyze and answer the influence of Transformational Leadership Style, Work Motivation, and Work Environment on Employee Innovation Performance at PT. PLN Persero ULP Kangean Islands, Sumenep Regency, this study took respondents from a total of 85 respondents and was taken from employees who worked at PT. PLN Persero ULP Kangean Islands, Sumenep Regency using saturated sampling technique

Multiple linear regression analysis techniques as a whole the indicators in the independent and dependent variables, show that the independent variables have a positive and significant effect on the dependent variable. The results of the correlation coefficient and determination coefficient show that all independent variables have a very strong and unidirectional influence on the dependent variable of $92.6 \%$, while the remaining $7.4 \%$ is influenced by other variables not examined. 


\section{A. PENDAHULUAN}

Seiring perkembangan zaman organisasi atau perusahaan diharapkan bisa menyaingi semua industry. Industry harus melakukan perkembangan agar dapat menyaingi perusahaan atau semua competitor. Oleh sebab itu pegawai atau (SDM) dijadikan sebuah pendorong pengelola yang sangat krusial untuk membangun industry untuk mendapat target yang ingin dicapai. Keberhasilan sebuah industry dipengaruhi dengan kemampuan pegawai baik telaten, oleh karna itu dibuat evaluasi kinerja karyawan agar organisasi mampu melihat sebagaimana karyawan berperanbagi perkembangan perusahaan.

Hal ini juga berlaku bagi perusahaan-perusahaan milik negara seperti PT. PLN Persero sebagai penyedia jaringan listrik bagi masyarakat. Oleh karena itu PT. PLN Persero juga perlu untuk terus meningkatkan kualitas SDM yang berada di lingkup perusahaan agar tujuan yang sudah direncanakan bisa berjalan maksimal, baik untuk memberikan servis yang bagus bagi pelanggan maupun sebagai perusahaan yang dapat menyumbangkan keuntungan bagi negara.

Dalam rangka memperluas jangkauan terhadap masyarakat, PT PLN Persero mendirikan unit-unit yang tesebar di seluruh pelosok negeri. Salah satu unit yang dimiliki oleh PT. PLN Persero adalah Unit Layanan Pelanggan yang ada di Kepulauan Kangean Kabupaten Sumenep atau kemudian dikenal dengan nama ULP Kepulauan Kangean.

PT. PLN Persero ULP Kepulauan Kangean mendistribusikan dan mengelola listrik di dua kecamatan yang ada di Pulau Kangean, yakni Kecamatan Arjasa dan Kecamatan Kangayan. Adapun jumlah pelanggan yang terdaftar pada PT. PLN Persero ULP Kepualauan Kangean hingga saat ini sejumlah 37000 pelanggan dan jumlah tersebut terus mengalami peningkatan yang cukup pesat. Dengan jumlah pelanggan yang demikian banyak sedangkan jumlah karyawan yang hanya 85 orang, sudah termasuk jajaran menejerial hingga staff tingkat paling bawah tentu akan menjadikan tantangan tersendiri bagi PT. PLN Persero ULP Kepulauan Kangean.

Adapun tugas-tugas yang harus dilaksanakan oleh PT. PLN Persero ULP Kepulauan Kangean mulai dari pemasangan $\mathrm{KWH}$ baru, survey lapangan, pemeliharaan jaringan, serta keluhan atau laporan pelanggan yang sangat tinggi, hal ini dikarenakan masyarakat Kepulauan Kangean masih tergolong awam terutama terkait listrik prabayar yang baru digunakan beberapa tahun terakhir di Kepulauan Kangean, sehingga persoalan-persoalan sepele masih harus membutuhkan petugas PT. PLN Persero ULP Kepualuan Kangean.

Kondisi ini tentunya membutuhkan peningkatan kinerja dari para karyawan PT. PLN Persero ULP Kepualaun Kangean, mengingat tugas tugas yang harus diselesaikan dapat dikatakan cukup berat. Oleh karenanya kepemimpinan transformasional, motivasi kerja, dan lingkungan kerja sangatlah diperlukan sehingga tujuan organisasi dapat tercapai demi memberikan layanan yang maksimal.

Tabel 1.1.

Keterlambatan Karyawan

\begin{tabular}{|c|c|}
\hline Bulan & Jumlah karyawan \\
\hline Mei & 21 \\
\hline Juni & 16 \\
\hline
\end{tabular}




\begin{tabular}{|c|c|}
\hline Juli & 24 \\
\hline Agustus & 9 \\
\hline September & 19 \\
\hline Oktober & 14 \\
\hline
\end{tabular}

Sumber: data HRD PT. PLN Persero Kepulauan Kangean

Berdasarkan data keterlambatan pada tabel bisa diartikan kemampuan kerja pegawai PT. PLN Persero ULP Kepualauan Kangean masih tergolong sangat buruk. Hal ini tentu diperungi oleh beberapa faktor diantaranya gaya kepimpinan yang diterapkan, motivasi kerja para karyawan, serta area bisa memiliki peran bagi kemampuan kerja karyawan. Menurut pendapat para ahli

Merujuk pada permasalahan yang telah diuraikan, lalu amat bagus mengangkat riset dengan judul "Pengaruh Gaya Kepemimpinan Transformasional Motivasi Kerja Dan Lingkungan Kerja Terhadap Kinerja Inovasi Karyawan (Studi Pada PT. PLN Persero ULP Kepulauan Kangean Kabupaten Sumenep)"

tujuan penelitian yang ingin di capai

1. "Untuk mengetahui bagaimana pengaruh kepemimpinan transformasional terhadap kinerja inovasi karyawan PT. PLN Persero ULP Kepulauan Kangean"?

2. "Untuk mengetahui bagaimana pengaruh motivasi kerja kepada kinerja inovasi karyawan PT. PLN Persero ULP Kepulauan Kangean"?

3. 'Untuk mengetahui bagaimana pengaruh lingkungan kerja terhadap kinerja inovasi karyawan PT. PLN Persero ULP Kepulauan Kangean"?

\section{B. KAJIAN LITERATUR}

\section{Kepemimpinan Transfomasional}

"Menurut Robbins dan Judge (2008:90)" kepemimpinan transformasional ialah kepemimpin bisa mengarahkan semua bawahannya agar bisa menghilangkan keinginan tersendiri bawahannya agar mempunya ikeahlian akan mengarahkan. Oleh karna itu atasan harus bisa memberikan kepeduliannya agar bisa mengetahui apa saja keinginan ekspansi bagi semua karyawannya. Atasan pula perlu bisa mengubah pola pikir semua bawahannya akan masalah-masalah dengan membantu bawahannya menyelesaikan persoalan lama dengan menggunakan kemampuan yang baru.

\section{Motivasi Kerja}

Motivasi berkaitan dengan kemampuan mempengaruhi antusiasme karyawan, untuk karyawan mau beroprasi mendedikasikan keterampilannya dengan baik agar tercapai misi perusahaan. Motivasi menjadi bagian yang sangat krusial sebab motivasi sangat mempengaruhi antusiasme karyawan dalam melaksanakan tugasnya untuk mencapai tujuan dari perusahaan.

\section{Lingkungan Kerja}

Lingkungan kerja dapat dikatakan serupa kemampuan yang bisa mempengaruhi, secara tidak langsung maupun langsung bagi kemampuan kerja suatu perusahaan."Menurut Sedarmayati pada dasarnya ruang lingkup perusahaan adalah suatu alat atau sebuah masalah yang dihadapi, ruangan kerja dimana pegawai itu bekerja, prosedur kerjanya, peraturan kerjanya, Adapun untuk bekerja sendiri maupun berkelompok". 


\begin{abstract}
Kinerja Karyawan
SDM atau sumberdaya manusia dalam suatu perkumpulan adalah hal yang begitu berguna. Kemampuan kerja suatu Lembaga bisa berpengaruh bagi kemampuan kerja karyawang yang berada didadalm ruanglingkup perusahaan. Karna sebab itu, suatu perkumpulan membutuhkan keterampilan manusia sebagi faktor pendukung agar tujuan suatu perkumpulan dapat tercapai. Agar bisa meningkatkan produktivitas organisasi adalah dengan mengoptimalkan keterampila kerja karyawan.
\end{abstract}

\title{
C. METODOLOGI PENELITIAN
}

Riset ini merupakan riset asasosiatif kausal memakai ancangan kuantitatif. Riset berikut bermaksud agar bisa memahami dampak sebuah variabel, adalah sebuah riset asosiatif kausal "(Umar, 2005: 30)". analisis berikut akan menjabarkan ikatan sebuah variabel yang akan di analisa. Dalam riset berikut, peneliti memutuskan memilih method Kuantitatif. Metode ini memiliki artian sebagai Teknik atau cara dari peneliti untuk memanfaatkan sekumpulan sampel atau Sebagian kecail dari populasi yang telah ditentukan sebelumnya. Riset ini akan melakukan penelian tentang "Pengaruh Gaya Kepemimpinan Transformasional, Motivasi Kerja, dan Lingkungan Kerja terhadap Kinerja Inovasi Karyawan PT. PLN Persero ULP Kepulauan Kangean.

\section{Definisi Operasional dan Indikator Variabel Penelitian}

Variabel analisis ialah sebuah hal yang menyerupai apa saja yang telah ditentukan oleh peneliti agar bisa dipelajari untuk memperoleh informasi pristiwa tersebut, lalu disimpulkan. Variabel yang dipakai dalam riset ini di kategorisasikan menjadi variabel dependen dan variabel indipenden. Variabel dependen ialah variabel yang merupakan inti penelitian sebaliknya variabel independent ialah variabel yang sifatnya mempengaruhi variabel dependen, baik dampak yang ditimbulkan bersifat positif ataupun negatif.

\section{Populasi, Sampel, dan Teknik Pengambilan Sampel}

Dalam sebuah riset diperlukan sebuah penentuan Populasi, sampel, dan Teknik pengambilan data. Adapun populasi, sampel dan Teknik pengambilan data yang digunakan dalam riset ini ialah sebagai berikut.

1. Populasi

Populasi ialah sebuah ikatan dari semua element yang berupa kejadian, subjek dan orang yang mempunyai karakteristik sama menjadikan ketertarikan tersendiri bagi seorang peneliti karna bisa dianggap sebagai sebuah sumber penelitian. Populasi dalam riset yang dilakukan dalam penelitian ini adalah seluruh staf atau pegawai yang berada di PT. PLN Persero ULP Kepulauan Kangen yang berjumlah 85 orang.

2. Sampel

Sampel ialah sebuah bagian dari populasi, terdiri dari sebuah anggota populasi. Sampel ini diambil dalam sebuah permasalahan tidak memungkinkan untuk kita meneliti semua element populasi oleh sebab itu, kita harus membuat sebuah perwakilan populasi yang juga bisa dikatan sebagai sampel. Sampel dalam riset kali ini akan dilakukan kepada pegawai PT. PLN ULP Kepulauan Kangen pyang berjumlah 85 pegawai.

3. Teknik Pengmbilan Sampel

JIMF(Jurnal IImiah Manajemen Forkamma), Vol.4, No.2, Maret 2021 
Metode dalam pengambilan sampel dalam riset ini menggunakan Teknik sampling jenuh, adalah penentuan sampel apabila seluruh elemen populasi dijadikan sebagai sebuah sampel. Adapun hal ini selalu dilakukan bilamana jumlah populasi yang sedikit jumlahnya.

\section{Sumber dan Metode Pengumpulan data}

\section{Sumber data}

Sumber data yang diterapkan didalam riset kali ini ialah.

a. Data Primer

Data primer adalah sebuah data Analisa yang didapatkan secara langsung melalui basis asli atau tidak menempuh media penghubung. Data primer dalam analisah ini adalah sebuah jawaban dari responden melalui petunjuk-petunjuk melalui variabel yang telah ditetapkan.

\section{b. Data Sekunder}

Data sekunder ialah data yang didapat dari berbagai macam data yang sudah ada dengan kata lain yang sudah ada didalam perusahaan, Lembaga-lembaga riset dan semacamnya yang mempunyai model data. Data sekunder yang digunakan di riset ini ialah profil sebuah perusahaan, struktur organisasi, jumlah pegawai, dan nilai absensi.

\section{Metode Pengumpulan Data}

Teknik pengumpulan data ialah suatu cara yang dilakukan peneliti untuk memperoleh sebuah data yang terjadi dilapangan Adapun Teknik pengambilan data dalam penelitian ini menggunakan tehnik kuesioner, wawan cara dan studi Pustaka. Dalam riset ini, kuesioner yang digunakan adalah kuesioner tertutup yantu dengan model pertanyaan dimana pertanyaan tersebut sudah tersediah sebuah jawabannya langsung, sehingga responden hanya memilih dari alternatif jawaban yang sesuai dengan pendapatnya. Pertanyaan-pertayaan tertutup tersebut menyampaikan jawaban responden kepada variabel gaya kepemimpinan transformasional, motivasi kerja, lingkungan kerja dan kinerja inovasi karyawan. Kuesioner tersebut di bagikan kepada semua responden dan diharapkan semua responden memberikan jawaban yang ada dilam kuesioner tersebut menurut pendapatnya sendiri.

\section{Tempat dan Waktu Pengambilan Data}

Riset ini akan dilakukan di PT. PLN ULP Kepulauan Kangean Kabupaten Sumenep, Adapun waktu yang diperlukan dalam riset ini adalah sekitar 6 bulan mulai dari survey awal, penyusunan proposal hingga pengolahan data.

\section{Pengembangan Instrumen Penelitian}

1. Kisi-kisi Instrument

Kisi-kisi riset ini berbentuk angket, diamana angket ini berisi pertanyaan yang berkaitan dengan tiga variable yaitu gaya kepemimpinan transformsional, motivasi kerja dan lingkungan kerja.

2. Hasil uji instrument

Sebelum uji angket penelitian digunakan untuk Analisa yang sesungguhnya, angket riset ini diuji coba terlebih dahulu. Uji coba instrument dilakukan agar dapat mengetahui pengaruh terhadap besar kecilnya instrument yang disusun agar bisa menentukan bermutu tidaknya penelitian. Bagus buruknya instrument penelitian ditunjukkan oleh tingkay kesalahan dari (validity) dan keandalan (reliability). Uji coba 
instrument dimaksudkan agar bisa mengetahui validitas dan reliabilitas instrument agar bisa mengetahui layak tidaknya digunakan untuk pengumpulan data pada karyawan PT. PLN ULP Kepulauan Kangean.

\section{Uji kualitas data}

Uji validitas digunakan untuk dapat mengukur kuesioner tersebut valid atau atau tidak. Hasil dari Analisa yang valid apabila kedapatan keserupaan antara data yang terakumulasi dengan data yang sebenarnya terjadi pada objek yang dianalisa. Uji validitas dijadikan alat untuk menguji absah atau validnya sebuah kuesioner tersebut. Sebuah kuesioner bisa dikatakan valid apabila pertanyaan pada sebuah kuesioner bisa menjelaskan obejek yang ditetapkan oleh kuesioner tersebut. Untuk dapat menguji validitas dapat dilakukan dengan melaksanakan hubungan antara skor dan sebuah pertanyaan atas hasil skor konstruk atau variabel.

\section{Teknik Analisi Data}

Analisis data ialah serangkaian kegiatan sesudah data dari semua responden terakumulasi. Aktivitas dalam riset data ialah mengumpulkan data berlandaskan variabel dan macam-macam responden, mengkelompokkan data berlandaskan variabel dari semua responden, mengemukakan data dari setiap variabel yang dianalisa, melakuakan kalkulasi agar bisa menjawab rumusan masalah, dan melakukan kalkulasi agar dapat menguji hipotesis yang telah diserahkan. Oleh karna itu dinyatakan bahwa riset data perlu diterapkan, sebagai angkah berikutnya sesudah semuah data dari lapangan terhimpun, juga bermaksud mengatur dan mendefinisikan hasil dari pengolahan data tersebut beserta kesimpulannya. 


\section{HASIL DAN PEMBAHASAN}

\section{Gambaran Umum Objek Penelitian}

\section{Struktur Organisasi}

Struktur organisasi adalah sebuah hal paling penting yang dapat mempengaruhi keberhasilan dari sebuah industry. Struktur organisasi ini mempunyai peranan yang sangat krusial dalam kemajuan sebuah industry dimana struktur organisasi ini merupakan gambaran dari sebuah perusahaan dalam melakukan tugas atau tanggung jawabnya agar dapat mencapai tujuan dari perusahaan.

Gambar 4.1

Struktur Organisasi

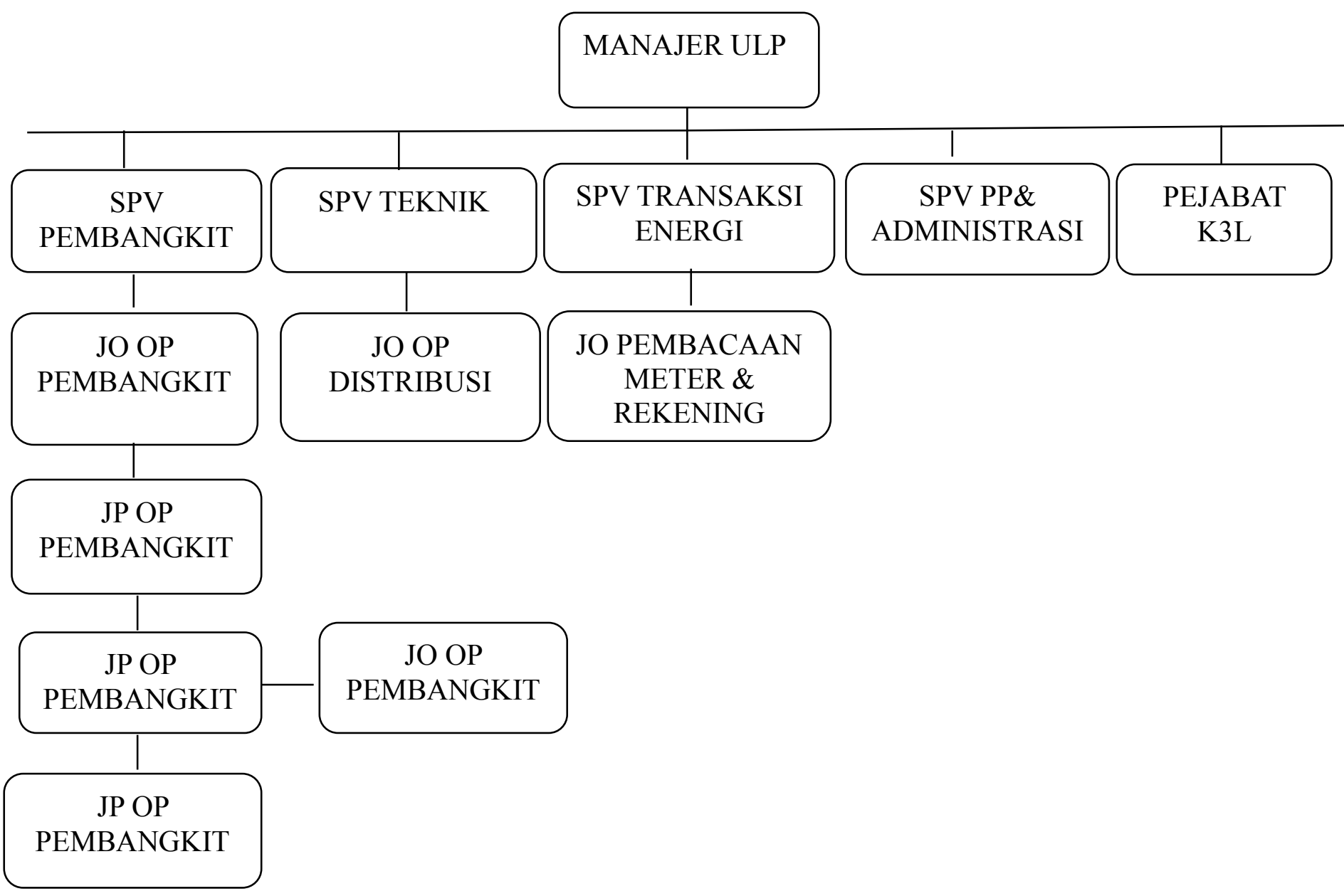




\section{Deskripsi Hasil Penelitian}

Penelitian deskriptif bermaksud untuk menjabarkan krakteristik responden dan jawaban dari responden di dalam pertanyaan-pertanyaan di dalam kuesioner untuk masing-masing variable, agar dapat menyimpulkan hasil dari jawaban dari semua responden. Di dalam riset ini, responden yang diteliti ialah semua pegawai yang bekerja di PT. PLN Persero ULP Kepulauan Kangean dengan jumlah sampel 85 pegawai.

\section{Karakteristik Berdasarkan Jenis Kelamin Tingkat Pendidikan dan Jabatan}

Penjelasan berdasarkan karakteristik responden adalah gambaran umum agar dapat meneliti perbedaan antar setiap orang. Dalam riset ini, ada sebanyak 85 responden sudah berpartisipasi dalam mengisi kuesioner yang sudah di berikan oleh peneliti dengan lengkap. Semua responden yang berpartisipasi dalam riset ini merupakan semuah pegawai yang bekerja di PT. PLN ULP Kepulauan Kangean. Pada bagian ini akan di uraikan profil atau karakteristik responden yang mencangkup jenis kelamin, tingkat Pendidikan, dan jabatan responden.

Bisa dilihat dari hasil riset sebanyak sebanyak 85 orang responden, bahwa pada karakteristik jenis kelamin responden menyatakan bahwa frekuensi paling banyak diperoleh oleh jenis kelamin laki-laki yaitu sebanyak 71 orang responden ataupun dapat dipersentasikan menjadi $83,5 \%$ sebaliknya untuk responden yang berjenis kelamin perempuan sebanyak 14 responden ataupun dapat di persentasikan menjadi 16,5\%

Pada hasil riset berdasarkan tingkat Pendidikan, bisa dilihat bahwa frekuensi paling banyak diperoleh pada responden yan tingkat pendidikannya S1 sejumlah 46 responden atau bisa dipersentasikan menjadi $54,1 \%$ sebaliknya untuk frekuensi yang paling rendah terdapat pada responden yang memiliki tingkat Pendidikan D3 yaitu sejumlah 17 responden atau bisa di persentasikan mendai $20 \%$.

Untuk distribusi frekuensi jabatan memperlihatkan bahwa frekuensi terbanyak terdapat pada responden yang mempunyai jabatan staff sejumlah 35 responden atau bisa dipersentasikan menjadi $41,2 \%$ sebaliknya untuk frekuensi yang paling rendah diperoleh pada responden yang mempunyai jabatan manager yaitu sejumlah 4 orang responden atau bisa dipersentasikan menjadi 4,7\%. Agar dapat mengetahui lebih jelas bisa dilihat pada bagan berikut

\section{Bagan 4.1}

Karakteristik Responden

\begin{tabular}{|c|c|c|c|c|}
\hline No & $\begin{array}{l}\text { Karakteristik } \\
\text { Responden }\end{array}$ & Klasifikasi Karakteristik & Jumlah & $\begin{array}{c}\text { Persentase } \\
(\%)\end{array}$ \\
\hline 1 & Jenis Kelamin & $\begin{array}{ll}\text { - } & \text { Laki-laki } \\
\text { - } & \text { Perempuan } \\
& \text { Jumlah }\end{array}$ & $\begin{array}{l}71 \\
14 \\
85\end{array}$ & $\begin{array}{l}83,5 \\
16,5 \\
100\end{array}$ \\
\hline 2 & Tingkat Pendidikan & $\begin{array}{ll}\text { - } & \text { SMA } \\
\text { - } & \text { D3 } \\
\text { - } & \text { S1 } \\
\text { - } & \text { S2 } \\
\text { - } & \text { Jumlah }\end{array}$ & $\begin{array}{c}18 \\
17 \\
46 \\
4 \\
85\end{array}$ & $\begin{array}{c}21,2 \\
20 \\
54,1 \\
4,7 \\
100\end{array}$ \\
\hline
\end{tabular}




\begin{tabular}{|c|c|c|c|c|}
\hline 3 & Jabatan & $\begin{array}{ll}\text { - } & \text { MANAGER } \\
\text { - } & \text { SPV } \\
\text { - } & \text { STAFF } \\
\text { - } & \text { YANTEK } \\
\text { - } & \text { SATPAM } \\
\text { - } & \text { LAINNYA } \\
\text { - } & \text { Jumlah }\end{array}$ & \begin{tabular}{c|}
4 \\
17 \\
35 \\
9 \\
5 \\
15 \\
85
\end{tabular} & $\begin{array}{c}4,7 \\
20 \\
41,2 \\
10,6 \\
5,9 \\
17,6 \\
100\end{array}$ \\
\hline
\end{tabular}

\section{Uji Validitas}

\section{Bagan 4.7}

\begin{tabular}{|c|c|c|c|c|}
\hline Variabel & Dinyatakan & $\mathbf{r}_{\text {hitung }}$ & $r_{\text {tabel }}$ & Kesimpulan \\
\hline \multirow{9}{*}{$\begin{array}{c}\text { Gaya } \\
\text { Kepemimpinan } \\
\text { Transformasional } \\
\left(\mathbf{X}_{1}\right)\end{array}$} & GKT1 & 0,354 & 0,2133 & Valid \\
\hline & GKT2 & 0,329 & 0,2133 & Valid \\
\hline & GKT3 & 0,301 & 0,2133 & Valid \\
\hline & GKT4 & 0,807 & 0,2133 & Valid \\
\hline & GKT5 & 0,784 & 0,2133 & Valid \\
\hline & GKT6 & 0,603 & 0,2133 & Valid \\
\hline & GKT7 & 0,515 & 0,2133 & Valid \\
\hline & GKT8 & 0,804 & 0,2133 & Valid \\
\hline & GKT9 & 0,798 & 0,2133 & Valid \\
\hline \multirow{5}{*}{$\begin{array}{c}\text { Motivasi Kerja } \\
\left(\mathrm{X}_{2}\right)\end{array}$} & MK1 & 0,782 & 0,2133 & Valid \\
\hline & MK2 & 0,713 & 0,2133 & Valid \\
\hline & MK3 & 0,705 & 0,2133 & Valid \\
\hline & MK4 & 0,626 & 0,2133 & Valid \\
\hline & MK5 & 0,327 & 0,2133 & Valid \\
\hline \multirow{7}{*}{$\begin{array}{l}\text { Lingkungan } \\
\text { Kerja } \\
\left(\mathbf{X}_{3}\right)\end{array}$} & LK1 & 0,869 & 0,2133 & Valid \\
\hline & LK2 & 0,871 & 0,2133 & Valid \\
\hline & LK3 & 0,858 & 0,2133 & Valid \\
\hline & LK4 & 0,857 & 0,2133 & Valid \\
\hline & LK5 & 0,488 & 0,2133 & Valid \\
\hline & LK6 & 0,570 & 0,2133 & Valid \\
\hline & LK7 & 0,461 & 0,2133 & Valid \\
\hline \multirow{4}{*}{$\begin{array}{c}\text { Kinerja Inovasi } \\
\text { Karyawan } \\
(Y)\end{array}$} & KIK1 & 0,811 & 0,2133 & Valid \\
\hline & KIK2 & 0,782 & 0,2133 & Valid \\
\hline & KIK3 & 0,708 & 0,2133 & Valid \\
\hline & KIK4 & 0,686 & 0,2133 & Valid \\
\hline
\end{tabular}

Sumber : Data diolah

Berlandaskan bagan 4.7 hitungan uji validitas penjelasan pada variabel terikat maupun variabel bebas sudah meyakinkan, karena nilai $r_{\text {hitung }}>r_{\text {tabel }}$. Bisa dikatakan seluruhnya variabel riset sudah meyakinkan.

\section{Relibilitas}

\section{Bagan 4.8}


Hasil Uji RELIBILITAS

\begin{tabular}{lccc}
\hline Variabel & $\begin{array}{c}\text { Cronbach's } \\
\text { Alpha }\end{array}$ & Alpha & Kesimpulan \\
\hline $\begin{array}{l}\text { Gaya Kepemimpinan } \\
\text { Transfomasional }\left(\mathbf{X}_{\mathbf{1}}\right)\end{array}$ & 0,741 & 0,60 & Teruji \\
\hline Motivasi Kerja $\left(\mathbf{X}_{\mathbf{2}}\right)$ & 0,750 & 0,60 & Teruji \\
\hline Lingkungan Kerja $\left(\mathbf{X}_{\mathbf{3}}\right)$ & 0.797 & 0,60 & Teruji \\
\hline $\begin{array}{l}\text { Kinerja Inovasi } \\
\text { Karyawan }(\mathbf{Y})\end{array}$ & 0.795 & 0,60 & Teruji \\
\hline
\end{tabular}

Sumber : Data diolah

Berlandaskan Bagan 4.8 memperlihatkan perolehan dari "reliabilitas" baik pada variabel terikat dan variabel bebas yang sudah di uji yaitu Gaya Kepmimpinan Transformasional, Motivasi Kerja, Lingkungan Kerja dan Kinerja Inovasi pegawai memperlihatkan reliabel semua, bahwasanya hasil Cronbach's Alpha > dominan dari 0,60 bisa dikatakan kalau semua variabel telah reliabel.

Uji T

Bagan 4.11

Hasil Analisis Uji T

\begin{tabular}{|l|r|rr|}
\hline \multicolumn{1}{|c|}{ Variabel } & \multicolumn{2}{c|}{ Uji T } \\
\cline { 2 - 4 } & \multicolumn{1}{|c|}{ t } & Sig \\
\hline $\begin{array}{l}\text { Gaya KepemimpinanTransformasional } \\
\left(\mathbf{X}_{\mathbf{1}}\right)\end{array}$ & 3.515 & .001 \\
\hline \hline Motivasi Kerja $\left(\mathrm{X}_{2}\right)$ & 9.088 & .000 \\
\hline Lingkungan Kerja $\left(\mathrm{X}_{3}\right)$ & 4.750 & .000 \\
\hline
\end{tabular}

Sumber : Data diolah

Dilihat Dari Kotak 4.11, di dapatkan hasil pengujian sebagai berikut

Uji Parsial antar variabel Gaya Kepemimpinan Transformasional (X1) Terhadap Kinerja Inovasi Karyawan (Y)

1. $\mathrm{HO}: \beta<0$ : (Adalah, variabel Gaya Kepemimpinan Transformasional tidak memepunyai dampak berarti terhadap Kinerja Inovasi Karyawan)

2. Ha: $\beta>0$ : (Adalah, variabel Gaya Kepemimpinan Transformasional punya dampak berarti kepada Kemapuan kerja Inovasi pegawai)

Berlandaskan hasil analisis regresi, Nilai t hitung Gaya Kepemimpinan Transformasional sejumlah 3,515 beserta nilai signifikansi 0,001 . Hasil $t$ hitung $(3,515)>t_{\text {table }}(1,988)$. Padahal, nilai Relevan Uji T sejumlah 0,001 > daripada $\alpha$ sebesar $5 \%$ maka $\mathrm{H}_{0}$ ditolak, Ha diterima membuat simpulannya secara parsial variabel Gaya Kepemimpinan Transformasional memiliki dampak kepada Kinerja Inovasi Karyawan. Arah dampak Gaya kepemimpinan transformasional kepada kemampuan kerja ialah positif. Sebab karna itu, semakin tinggi Gaya Kepemimpinan Transformasional yang diberikan kepada Pegawai, bisa meningkatkan kemampuan kerja Inovasi pegawai dan sebaliknya makin rendah 
Gaya Kepemimpinan Transformasional yang diberikan, membuat akan makin rendah Kinerja Inovasi Karyawan.

Uji Parsial antar Variabel Motivasi Kerja (X2) Kepada Kinerja Inovasi Kariyawan(Y)

1. $\mathrm{HO}: \beta<0$ : (Adalah,variabel Motivasi Kerja gak mempunyai dampak relevan kepada kemampuan kerja Inovasi Karyawan)

2. $\mathrm{Ha}: \beta>0$ : (adalah, variabel motivasi kerja mempunyai dampak relevan kepada kemampuan kerja Inovasi Karyawan)

Berlandaskan ulasan regresi, hasil hitung T varibel Motivasi Kerja sejumlah 9,088 Dan jumlah signifikansi 0,000 . Hasil $t$ nitung $(9,088)>t$ tabel $(1,988)$. adapun,nilai relevan uji t sejumlah $0,000<$ daripada $\alpha$ senilai $\mathbf{5} \%$ maka $\mathrm{H}_{0}$ ditolak, Ha diterima oleh karna itu kesimpulannya secara parsial variabel Motivasi Kerja mempunyai dampak kepada Kinerja Inovasi Karyawan. Alur dampak Motivasi Kerja akan Kinerja Inovasi Karyawan ialah positif.oleh karna itu, semakin besar Motivasi Kerja diberikan kepada pegawai lebih besar kemampuan kerja Inovasi pegawai begitu juga lebih kecil motivasi kerja diberikan kepada pegawai juga akan lebih rendah kemampuan kerja Inovasi Pegawai.

\section{Uji Parsiar Antara Vriabel Lingkungan Kerja Terhadap Kinerja Inovasi Karyawan (Y)}

1. $\mathrm{HO}: \beta<0$ : (ialah, variabel Lingkungan Kerja tidak punya dampak signifikan kepada kemampuan kerja Inovasi pegawai)

2. $\mathrm{Ha}: \beta>0$ : (adalah, variabel Lingkungan Keja mempunyai dampak yang signifikan terhadap Kinerja Inovasi Karyawan)

Berlandaskan hitungan analisis regresi, jumlah t hitung variabel Lingkungan Kerja sejumlah 4,750 dan dengan hasil sig 0,000 perolehan $\mathrm{T}$ hitung $(4,750)>\mathrm{t}$ tabel (1,980).Adapun, nilai signifikansi uji t sejumlah $0,000<\alpha$ senilai $5 \%$ maka $\mathrm{H}_{0}$ ditolak, Ha diterima membuat secara parsial simpulannya variabel Lingkungan punya dampak kepada Kinerja Inovasi Karyawan. Alur pengaru Lingkungan Kerja Kinerja Inovasi Karyawan ialah positif .oleh sebab itu, semakin besar Lingkungan Kerja yang dikasihkan terhadap pegawai, membuat meningkat Kinerja Inovasi Karyawan begitu juga lebih kecil Lingkungan Kerja dikasikan terhadap pegawai membuat lebih melemah Kinerja Inovasi Karyawan.

\section{Pembahasan \\ Pengaruh Gaya KepemimpinanTransformasional Terhadap Kinerja Inovasi Karyawan}

Riset ini bertujuan guna bisa mengukur dampak variable bebas Gaya Kepemimpinan Transformasional $\left(X_{1}\right)$ Yang berpartisipasi sebagai segmental kemampuan kerja Inovasi pegawai(Y). melalui riset ini, dampak variabell Gaya Kepemimpinan Transformasional sebagai segmental kepada kemampuan kerja Inovasi pegawai diteliti melalui uji t yang memperlihatkan hasilnya 0,001<0,05 bisa dikatan didapati dampak relevan kepada variabel Gaya Kepemimpinan Transformasional terhadap Kinerja Inovasi Karyawan. karna itu teori awal dalam riset ini yaitu "Gaya kepemimpinan transformasional mempunyai pengaruh positif dan signifikan kepada kinerja inovasi karyawan" bisa dikatakan layak.

Dampak antara variabel Gaya Kepemimpinan Transformasional dengan kinerja Inovasi karyawan ialah positif yang memberitahu adanya ikatan sehaluan atau bisa dikatakan bahwa semakin besar tingkat Gaya Kepemimpinan Transformasional yang di peroleh karyawan di PT. PLN Persero ULP Kepulauan Kangean tentu akan selalu JIMF(Jurnal IImiah Manajemen Forkamma), Vol.4, No.2, Maret 2021 
meningkatkan kemampuan kerja Inovasi Karyawan. adapun Kinerja Inovasi Karyawan bisa dibentuk melalui Gaya Kepemimpinan Transformasional yang bagus dan mampu mengembakan inovasikemampuan kerja.

\section{Pengaruh Motivasi Kerja Terhadap Kinerja Inovasi Karyawan}

Riset berikut bermaksud guna memahami dampak motivasi kerja variabel bebas $\left(\mathrm{X}_{2}\right)$ selaku segmental kepada kemampuan kerja Inovasi pegawai $(\mathrm{Y})$ dalam riset berikut , dampak vriabel motivasi kerja sebagai segmental kepada kemampuan kerja Inovasi pegawai diteliti dengan uji $\mathrm{T}$ memperlihatkan hasil sig $0,000<0,05$ bisa diartikan damapak signifikan Motivasi Kerja kepada Kinerja Inovasi pegawai. Adapun asumsi dalam riset ini yaitu "Motivasi kerja mempunyai pengaruh positif dan signifikan akan kinerja inovasi karyawan.",bisa dikatakan layak.

Dampak dari variabel Motivasi kerja dan kinerja Inovasi karyawan ialah positif yang memperlihatkan adanya ikatan sehaluan dapat pula diartikan maka semakin baik Motivasi kerja yang disampaikan terhadap karyawan akan memberikan peningkatan kinerja Inovasikaryawan. Adapun kinerja inovasi karyawan bisa di bentuk dengan adanya Kinerja Inovasi Karyawan, sehingga apabila PT. PLN Persero ULP Kepulauan Kangean ingin meningkatkan Kinerja Inovasi Karyawan maka pemimpin harus memberikan motoivasi kepada karyawan dengan kualitas yang baik.

\section{Pengaruh Lingkungan Kerja Terhadap Kinerja Inovasi Karyawan}

Riset ini bertujuan guna bisa memahami dampak variabel bebas Lingkungan kerja $\left(\mathbf{X}_{3}\right)$ sebagai parsial akan kinerja inovasi karyawan (Y).riset ini, dampak variable Lingkungan kerja selaku parsial akan kinerja inovasi karyawan diteliti memakai uji t yang memperlihatkan angka SIG seniali $0,000<0,05$ bisa diartikan diproleh dampak signifikan Lingkungankerja kepada kemampuan kerja inovasi pegawai. Adapun asumsi 3 diriset ini adalah "Lingkungan kerja mempunyai pengaruh positif dan signifikan terhadap kinerja inovasi karyawan.", bisa dikatakan layak.

Dampak atar variable Lingkungan kerja dengan kinerja Inovasi karyawan adalah positif yang memperlihatkan adanya kaitan sehaluan bisa dikatakan bila semakin baik lingkungan kerja atau ruangan yang diberikan kepada karyawan PT. PLN Persero ULP Kepulauan Kangean, maka bakal semakin bertambah kinerja Inovasi karyawan. Adapun kinerja Inovasi karyawan bisa disusun dengan adanya lingkungan kerja , sehingga apabila PT. PLN Persero ULP Kepulauan Kangean ingin meningkatkan Kinerja Inovasi Karyawan oleh karna itu penting akan memperhatikan lingkungan kerja yang di berikan terhadap karyawan harus baik, bersih serta nyaman.

\section{E. KESIMPULAN}

Menurut riset yang dilakukan bisa diambil kesimpulan bahwa

1. Berdasarkan hasil Uji T (parsial), variabel Gaya Kepemimpinan Transformasional mempunyai dampak positif dan signifikan kepada kinerja Inovasi Karyawan. Perihal ini di lihat Pada nilai signifikan sebesar 0,001 $<0,05$, membuat hipotesis berdampak Gaya Kepemimpinan Transformasional terhadap Kinerja Inovasi Karyawan dapat diterima.

2. Berdasarkan hasil Uji T (parsial), variabel Motivasi Kerja mempunyai dampak positif dan signifikan akan Kinerja Inovasi Karyawan. Keadaan ini dilihat akan nilai signifikan sebanyak 0,000 $<0,05$, membuat hipotesis berpengaruh Motivasi Kerja terhadap Kinerja Inovasi Karyawan layak diakui.

3. Menurut hitungan percobaan T (parsial), variabel Lingkungan Kerja mempunyai dampak baik kepada Kinerja Inovasi pegawai. keadaan ini dilihat terhadap nilai signifikan sebesar 0,000 $<0,05$, membuat hipotesis berdampak pada Lingkungan Kerja terhadap Kinerja Inovasi Karyawan layak diakui. 


\section{Saran}

Berlandaskan hasil analisis dan pengkajian yang dilakukan, peneliti memberikan saran atau masukan yang bisa dibuat acuan oleh PT. PLN ULP Kepulauan Kangean dalam meningkatkatkan Kinerja Inovasi Karyawan juga bagi peneliti selanjutnya. Adapun saransaran tersebut adalah sebagai berikut.

Untuk PT. PLN ULP Kepulauan Kangean

2. Di harapkan pemimpin agar selalu menjaga gaya kepemimpinan yang baik bagi karyawan agar selalu bisa meningkatkan kinerja inovasi karyawan.

3. Di harapkan pemimpin agar pemimpin perusahaan selalu bisa memotivasi karyawannya agar karyawan dapat terus meningkatkan inovasi kinerjanya didalam perusahaan.

4. Di harapkan pemimpin agar selalu menciptakan rasa aman dan nyaman bagi semua karyawan di dalam lingkungan kerja sehingga karyawan bisa bekerja dengan baik dalam perusahaan.

Di tujukan untuk peneliti selanjutnya.

1. Diharapkan agar peneliti selanjutnya agar bisa mengembangkan hasil riset ini dengan menambahkan faktor-faktor lainya yang bisa mempengaruhi kinerja inovasi karyawan dengan metode penelitian yang berbeda.

\section{DAFTAR PUSTAKA}

Kadim, A., Sunardi, N., Lesmana, R., \& Sutarman, A. (2019). Revitalisasi Fungsi Masjid Sebagai Pusat Penguatan Manajemen Peternak Sapi Rakyat melalui Lembaga Pemberdayaan Masyarakat Terpadu (LEMPERMADU).(Studi Kasus di Masjid Ainul Yaqin Kel. Jontlak, Kec. Praya, Kab. Lombok Tengah, Provinsi Nusa Tenggara Barat). Jurnal Abdi Masyarakat Humanis, 1(1).

Lesmana, R., Sunardi, N., Hastono, H., \& Widodo, A. S. (2021). Perceived Quality Membentuk Customer Loyalty via Brand Equity pada Pengguna Smartphone Merek Xiaomi di Tangerang Selatan. Jurnal Pemasaran Kompetitif, 4(2), 157-167.

Lesmana, R., Widodo, A. S., \& Sunardi, N. (2020). The Formation of Customer Loyalty From Brand Awareness and Perceived Quality through Brand Equity of Xiaomi Smartphone Users in South Tangerang. Jurnal Pemasaran Kompetitif, 4(1), 1-12.

Mas'ud, Fuad. (2004). Survey Diagnosis Organizational. Semarang: UNDIP.

Nardi Sunardi Et Al (2020). Determinants of Debt Policy and Company's Performance, International Journal of Economics and Business Administration Volume VIII Issue 4, 204-213

Rivai, V. (2004). Manajemen SDM Untuk Perusahaan Dari Teori Ke Praktik. Jakarta: PT Raja Grafindo Persada."

Rivai, Veithzal \& Dedy Mulyadi. (2009). Kepemimpinan Dan Perilaku Organisasi. Jakarta: PT. Raja Grafindo Persada."

Rivai, Veithzal Fawzi, \& Basri, M.A. (2005). Performance Appraisal. Jakarta: PT. Raja

Rivai, Veithzal. 2005. Performance Appraisal. Jakarta: PT. Raja Grafindo Persada. 
Robbins, Stephen P. (2006). Perilaku Organisasi. Edisi Kesepuluh. Jakarta: Salemba Empat"

Robbins, Stephen P. 2002. Prinsip-Prinsip Perilaku Organisasi. Edisi 5. Alih Bahasa: Halida, Dewi Sartika. Jakarta: Erlangga."

Robbins, Stephen., dan Timothy A. J., 2008. Perilaku Organisasi, Organizational Behaviour, Buku terjemahan. Jakarta : Gramedia."

Saydam Gouzali. (2000). Manajemen Sumber Daya Manusia: Suatu pendekatan Mikro (dalam Tanya Jawab). Jakarta: Djambatan."

Saydam, G. (1996). Manajemen Sumber Daya Manusia. Jakarta: Gunung Agung

Sedarmayanti. (2001). Sumber Daya Manusia dan Produktivitas Kerja.Bandung: Mandar Maju."

Sunardi, N., \& Lesmana, R. (2020). Konsep Icepower (Wiramadu) sebagai Solusi Wirausaha menuju Desa Sejahtra Mandiri (DMS) pada Masa Pandemi Covid19. JIMF (Jurnal IImiah Manajemen Forkamma), 4(1).

Wirawan. (2009). Evaluasi Kinerja Sumber Daya Manusia: Teori, Aplikasi, dan Penelitian. Jakarta: Salemba Empat"

Wirawan. 2009. Evaluasi Kinerja Sumber Daya Manusia : Teori Aplikasi dan Penelitian.

Yukl, Gary A. 2010. Kepemimpinan Dalam Organisasi (Terjemahan). Alih bahasa: Budi Supriyanto. Edisi kelima. Jakarta: PT. Indeks." 